Transportation Research Forum

Freight Transportation Demands on the Upper Mississippi and Illinois Rivers

Author(s): Tun-Hsiang Yu, Jin Zhang, and Stephen Fuller

Source: Journal of the Transportation Research Forum, Vol. 45, No. 2 (Summer 2006), pp. 119-136

Published by: Transportation Research Forum

Stable URL: http://www.trforum.org/journal

The Transportation Research Forum, founded in 1958, is an independent, nonprofit organization of transportation professionals who conduct, use, and benefit from research. Its purpose is to provide an impartial meeting ground for carriers, shippers, government officials, consultants, university researchers, suppliers, and others seeking exchange of information and ideas related to both passenger and freight transportation. More information on the Transportation Research Forum can be found on the Web at www.trforum.org. 


\title{
Freight Transportation Demands on the Upper Mississippi and Illinois Rivers
}

\author{
by Tun-Hsiang Yu, Jin Zhang and Stephen Fuller
}

This paper estimates structural demands for grain transportation on the upper Mississippi and Illinois Rivers. Grain is the predominant commodity transported on these waterways. Analysis indicates Seemingly Unrelated Regression (SUR) to be a superior method for estimating each waterway's structural demand. Results show rates, foreign and domestic demands, floods, season, and river water level influence demands. Further, the analysis suggests that a detailed analysis of river freight demand is a necessary precursor of a defendable study into the economic feasibility of improving transportation infrastructure on the upper Mississippi and Illinois Rivers.

\section{INTRODUCTION}

Regan, Holguin-Vergas, Chow and Sonstegaard (2000) observe that knowledge of freight transportation demand is central to transportation planning, and lack of research initiatives in this area poses significant obstacles for transportation planners. The purpose of this study is to estimate freight transportation demands for the upper Mississippi and Illinois Rivers, two inland waterways important to freight transportation in the north central United States and transport arteries for which there is considerable debate regarding the need for infrastructure improvements.

The upper Mississippi River extends from near Minneapolis, Minnesota, to St. Louis, Missouri, and is a 663-mile segment of the Mississippi River, while the Illinois River extends from Chicago, Illinois, to its confluence with the upper Mississippi River (349 miles) just north of St. Louis, Missouri. Grain is the predominant commodity transported on these rivers, comprising about half the tonnage carried on the upper Mississippi and 40\% of the Illinois waterway tonnage; therefore, this study focuses on grain transportation demands (USACE 2004). Virtually all grain originating on these inland waterways is transported to lower Mississippi River ports (New Orleans, Louisiana) where it enters into international commerce. It is estimated that both rivers annually originate about 28 million tons (short tons) of corn or over half of U.S. corn exports, about $40 \%$ of U.S. soybean exports (12 million tons), and comparatively modest quantities of wheat (1.0 million tons) (USACE 2004). Both transport arteries are also important carriers of animal feed, coal, petroleum, fertilizer, construction materials, chemicals and metal (USACE 2004).

Navigation on the upper Mississippi and Illinois Rivers is facilitated by a system of dams that impound water for purposes of maintaining a 9-foot navigation channel. The upper Mississippi includes 25 dams, while the Illinois Waterway features eight dams. Navigation of these rivers is enabled by locks at each dam site that permit the barge tow to traverse the dam site for purposes of travel throughout the waterway. The lock and dam structures are aged and in the lower reaches of both rivers where traffic is heaviest; barge tows are required to wait an average of three to five hours at each lock site. Lock congestion is exacerbated by modern barge tows whose dimensions exceed that of most lock chambers, hence the necessity of time-consuming double-lockages. The U.S. Army Corps of Engineers (2004) has proposed that locks in the lower reaches of both rivers be replaced by locks whose chamber dimensions allow current tows to pass with a single lockage, thus reducing lock congestion. Unfortunately, the Corps feasibility study has been a source of concern, and at the request of the Corps the study has been evaluated by a committee appointed by the National Research Council (2004) that indicated needed changes in scope and improvements in methodology. 
Freight Transportation Demands

This study attempts to gain better insight into forces that influence the demand for grain transportation on two of the U.S.'s most important grain transport arteries, the upper Mississippi and Illinois Rivers. A review of literature revealed several efforts at estimation of freight demands for these waterways. Babcock and German (1983) estimated the demand elasticity for grain transportation on U.S. inland waterways to be -0.64. Harnish and Dunn (1998) estimated a reducedform model to explore the determinants of grain barge rates on the Mississippi River system in the short run. They selected eight segments of the Mississippi River system and conducted an individual and pooled estimation. Results indicate grain exports, coal barge rates, input costs, and distance influence grain barge rates. Miljkovic, Price, Hauser and Algozin (2000) estimated a structural model representing export-bound grain movement on the Illinois River corridor that included both rail and barge transport modes. The estimated supply and demand equations associated with the rail and barge markets linking Illinois to lower Mississippi River ports were inverse relationships (pricedependent equations); therefore, the own-price elasticities could not be obtained. They estimated a $1 \%$ increase in the supply of barge service would lower barge rate between -0.485 and $-0.541 \%$, and they found barges and railroads to be partial substitutes on the export grain movement. The quantity of grain exported, however, did not have a statistically important influence on the demand for either the barge or rail modes.

Recent studies of these waterways have focused on own-price demand elasticity because of the interest in proposed infrastructure improvements on the upper Mississippi and Illinois Rivers, and the insight on benefits offered by the demand relationship and its elasticity. Yu and Fuller (2005) studied grain barge demand on the upper Mississippi River. Their study evaluated factors thought to influence the River's grain transportation demand using monthly data from the 1992 to 1999 period. They estimated an own-price demand elasticity of -0.479 and found barge rates, foreign grain demand, rail rates, winter season, and floods to be influential variables. In contract reports to the U.S. Army Corps of Engineers, Dager, Bray, Murphree and Leibrock (2004) found the ownprice grain barge demand elasticity to range from -0.420 to -0.716 for various segments of the upper Mississippi and Illinois waterways. Boyer and Wilson (2005) examined the effect of barge rates on Mississippi River shipments of corn and estimated the barge rate elasticity to range between -0.02 and -0.35. Also, in a contract report to the Corps of Engineers, Hendrickson and Wilson (2005) evaluated forces that influence grain barge transportation demands using annual river elevator shipment data. In contrast to earlier studies, they found the own-price demand elasticity to be in the elastic range (-1.3 to -1.9$)$.

This paper attempts to estimate grain barge demands for the upper Mississippi and Illinois Rivers. An understanding of barge transportation demands will aid in determining the economic feasibility of infrastructure improvements on these waterways, in particular for the controversial expansion of the aging lock system. Information on forces that shift the barge demand schedule will provide necessary data for the feasibility analyses. In addition, using a system approach to estimate freight demands may provide insight not revealed by single-equation estimation methods and other methodologies employed in earlier efforts.

\section{THEORETICAL CONSIDERATIONS AND BACKGROUND}

The demand for grain barge transportation service that links the north central U.S. grain production region with lower Mississippi River ports is a derived demand; therefore, factors that shift grain supply and demand in the production region and export demand, as reflected at lower Mississippi River ports, will define and shift the demand for barge transportation (Boyer 1997). A two-region spatial equilibrium model is used to illustrate the theoretical foundation of grain barge demand (Figure 1). Panel A depicts the supply $\left(S_{x}\right)$ and demand $\left(D_{x}\right)$ of grain in the north central United States while Panel C represents the rest-of-the-world's (ROW) demand and supply for grain at lower Mississippi River ports. Panel B, the trade panel, includes the excess grain supply of the north central region $\left(E S_{x}=S_{x}-D_{x}\right)$ and the excess demand of the foreign regions that purchase grain at 
lower Mississippi River ports $\left(\mathrm{ED}_{\mathrm{m}}=\mathrm{D}_{\mathrm{m}}-\mathrm{S}_{\mathrm{m}}\right)$. The intersection of excess supply $\left(\mathrm{ES}_{\mathrm{x}}\right)$ and excess demand $\left(\mathrm{ED}_{\mathrm{m}}\right)$ relates the equilibrium price and quantity of grain traded between the north central U.S. and lower Mississippi River ports if no transportation costs were required to link the two regions. However, transportation costs are important in the marketing of grain. The derived demand for grain transportation and the supply of grain transportation service are represented in Panel D. The derived transportation demand is equal to the vertical distance between the excess supply (ES ${ }_{\mathrm{x}}$ ) and excess demand $\left(E_{m}\right)$ in Panel B. Also shown in Panel D is the supply of transportation service linking the north central U.S. to lower Mississippi River ports. Since barges transport the majority of grain from the north central region to lower Mississippi River ports, it is reasonable to presume the supply is an approximation of the grain barge fleet operating on the upper Mississippi River. The intersection of the derived transport demand and barge supply determines the transportation rate linking the north central U.S. to lower Mississippi River ports and the corresponding grain prices in the north central U.S. $\left(\mathrm{P}_{\mathrm{x}}\right)\left(\right.$ Panel A) and port area $\left(\mathrm{P}_{\mathrm{m}}\right)$ (Panel B), where grain prices in the two regions $\left(\mathrm{P}_{\mathrm{x}}\right.$ and $\left.\mathrm{P}_{\mathrm{m}}\right)$ differ by the barge transport rate that links the two regions. Any force shifting the regional supply $\left(\mathrm{S}_{\mathrm{x}}\right)$ and demand $\left(\mathrm{D}_{\mathrm{x}}\right)$ of grain in the north central U.S. will shift the excess supply of grain (ES $)$ and the derived transportation demand. Similarly, shifts in rest-of-theworld (ROW) excess grain demand and supply will also alter the derived demand for transportation. Therefore, these forces must be considered when specifying and estimating the demand for barge grain transportation.

In addition to the economic forces identified in the partial equilibrium representation in Figure 1 , transportation modes compete with and complement grain barge transportation on the upper

Figure 1: Two-Region Spatial Equilibrium Model and Derived Transportation Market

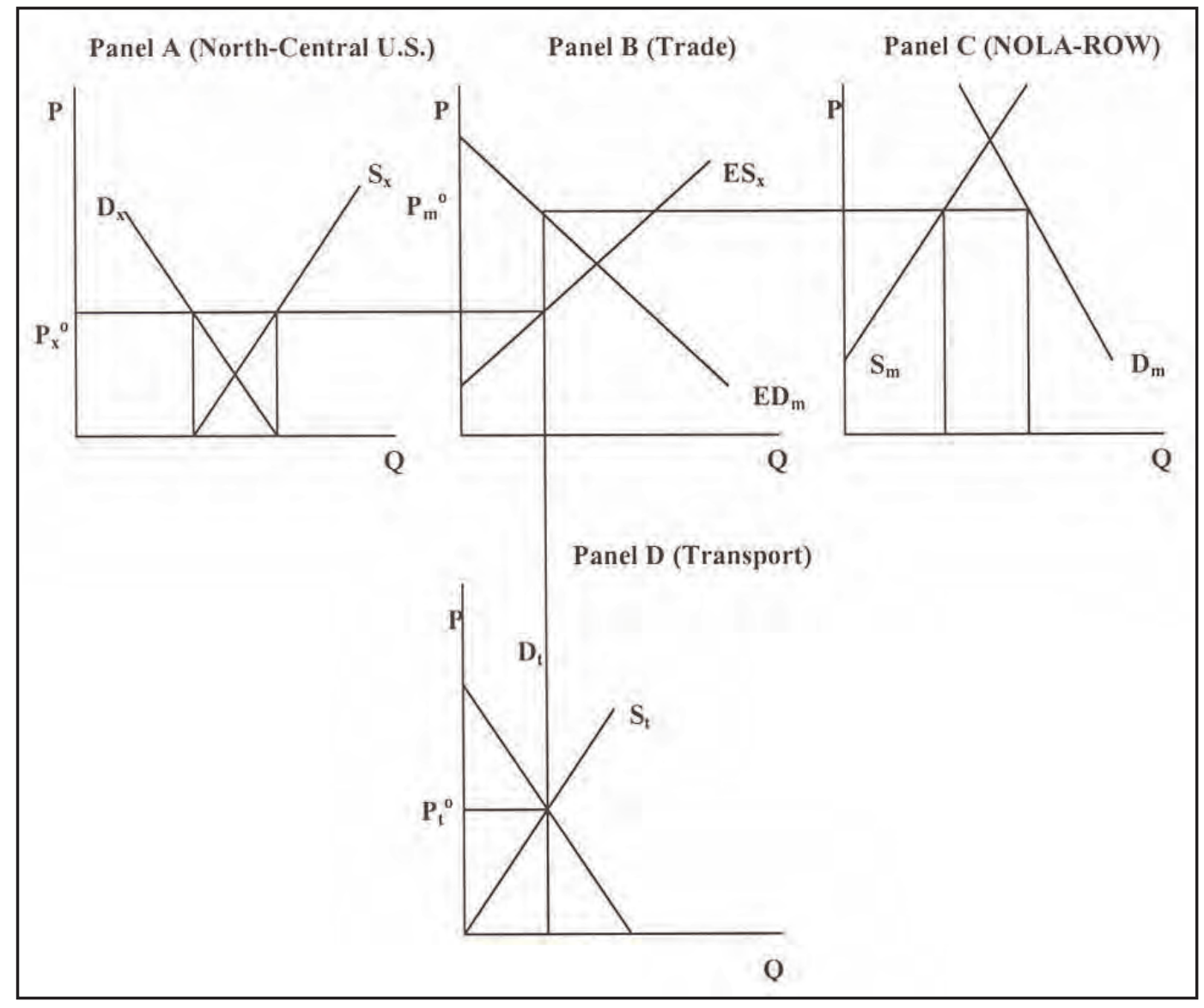


Freight Transportation Demands

Mississippi and Illinois Rivers. Although barges transport an estimated 90\% of the grain to lower Mississippi River ports, railroads may offer competition in portions of the U.S. Gulf port hinterland and, because all grain moved by barge must be assembled to river locations by truck and rail, a complementary relationship may also exist between barges and other transport modes (USDA 2005c). Grain shippers in states adjacent to the upper Mississippi River (e.g., Iowa and Minnesota) may find Pacific Northwest ports (PNW) an alternative to lower Mississippi River ports for purposes of accessing the Asian Basin market, the destination for about half of U.S. corn exports and twothirds of its soybean exports (USDA 2005d). According to carload waybill data from the Surface Transportation Board, in Minnesota the PNW was the most important corn and soybean export market served by railroads in the 1990-2002 period. In Iowa, the PNW was the most important export market served by railroads in about one-half of the years in the 1990-2002 time frame. Therefore, foreign grain demand as reflected at Pacific Northwest (PNW) ports and railroad rates linking the upper Mississippi River hinterland with the PNW port area may impact grain barge demand on the upper Mississippi River. In addition, the ocean carriers that link the PNW ports to Asia may offer competition to barges operating on the upper Mississippi, while ship rates linking lower Mississippi River ports to Asia may have a complementary relationship with grain barge transportation on these inland waterways.

\section{SPECIFICATION OF MODEL}

Based on the theoretical presentation, the following forces are believed to influence grain barge demands on both rivers:

(1) $q_{b, t}=f\left(q_{b, t-i}, p_{b, t}, \operatorname{exd}_{g, t}\right.$, domd $_{g, t}$, doms $\left._{g, t}, p_{o, t}, D_{t}\right)$

where $q_{b t}$ is the quantity of the grain barge service purchased by river grain shippers per unit of time $\mathrm{t}, p_{b, t}$ is the grain barge rate, $\operatorname{exd}_{g, t}$ is the grain export level, and $d o m d_{g, t}$ and $d o m s_{g, t}$ are the domestic demand and supply of grain, respectively. The $p_{o, t}$ variable is a proxy for transportation rates of other modes and $D_{t}$ are weather-related and seasonal binary variables.

Grain barge transport on the upper Mississippi and Illinois Rivers exhibits significant seasonality (Figures 2 and 3); therefore, the quantity of grain moved by barge in previous time periods (either past month or past year) may provide useful information regarding current barge demand. To capture this information, the lag(s) of the dependent variable, $q_{b, t}$ is (are) included in the demand equation. With this addition, the demand equation becomes a partial adjustment model: a special case of the autoregressive distributed lag (ADL) model (Davidson and MacKinnon 1993). The lagged structure facilitates the estimation of long-run demand elasticities that are important, given the extended life of the proposed infrastructure improvements on the upper Mississippi and Illinois Rivers.

There is interest in knowing the effect of barge rates on the quantity of grain barge service that is purchased; therefore, barge rate is included as an explanatory variable. The law of demand indicates an inverse relationship is expected between quantity of purchased transportation service and barge rate. Foreign grain demand would appear to have an important impact on the demand for barge grain transportation since most (about 95\%) of the grain barge movements on the upper Mississippi and Illinois Rivers are to lower Mississippi River ports (USACE 2003b). An increase in foreign grain demand is expected to shift the grain barge demand to the right, hence a positive relationship between foreign grain demand and the derived demand for grain transportation. The supply and demand schedule for grain in the north central U.S. region is also expected to influence grain barge demand. Regional grain supply is expected to influence the derived barge transport demand in a positive manner since an increase in grain supply ( $S_{x}$ in Panel A, Figure 1) will shift the excess supply curve (Panel B) and the derived barge demand curve rightward. In contrast, an increase in domestic grain demand will have a negative impact on barge grain transport demand due to the leftward shift of the excess grain supply curve and derived transport demand. 
Figure 2: Quantity of Corn and Soybeans Transported by Barge on the Upper Mississippi River

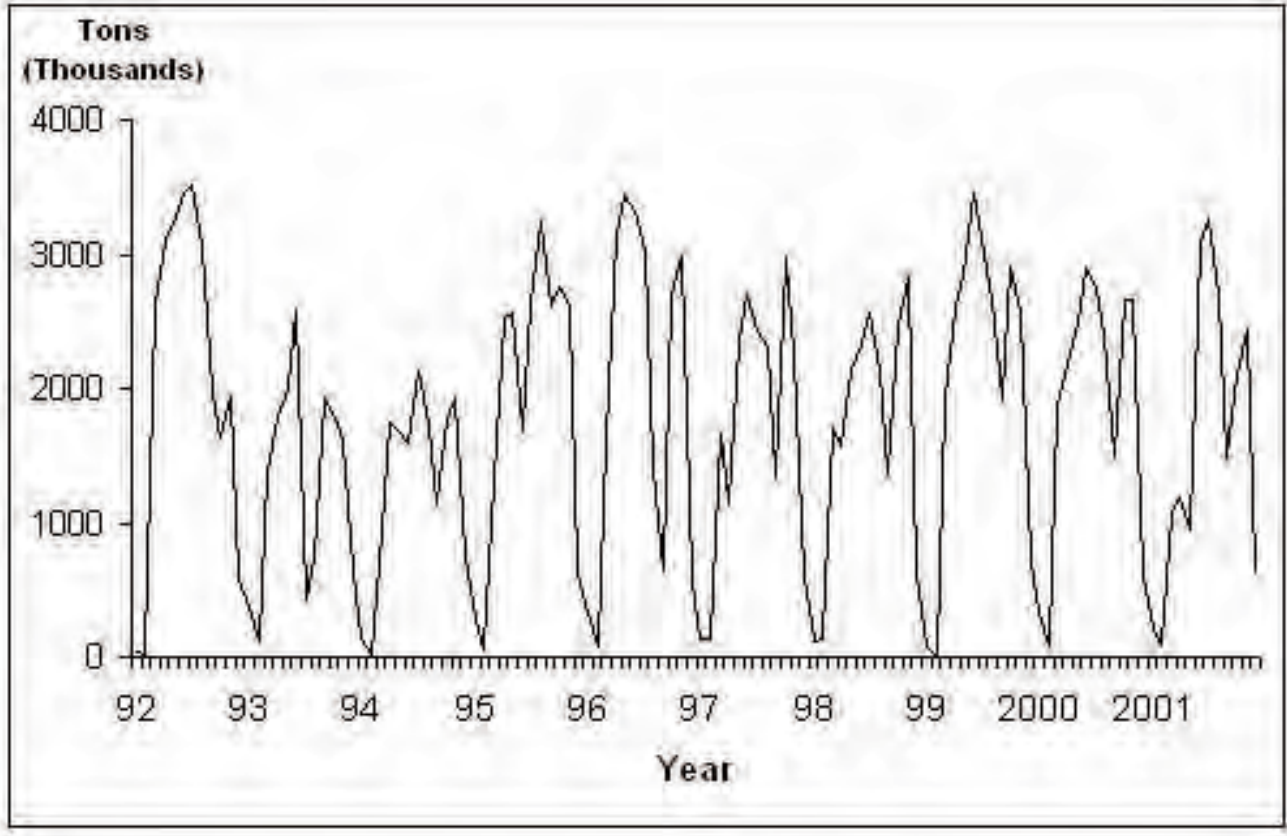

Figure 3: Quantity of Corn and Soybeans Transported by Barge on the Illinois River

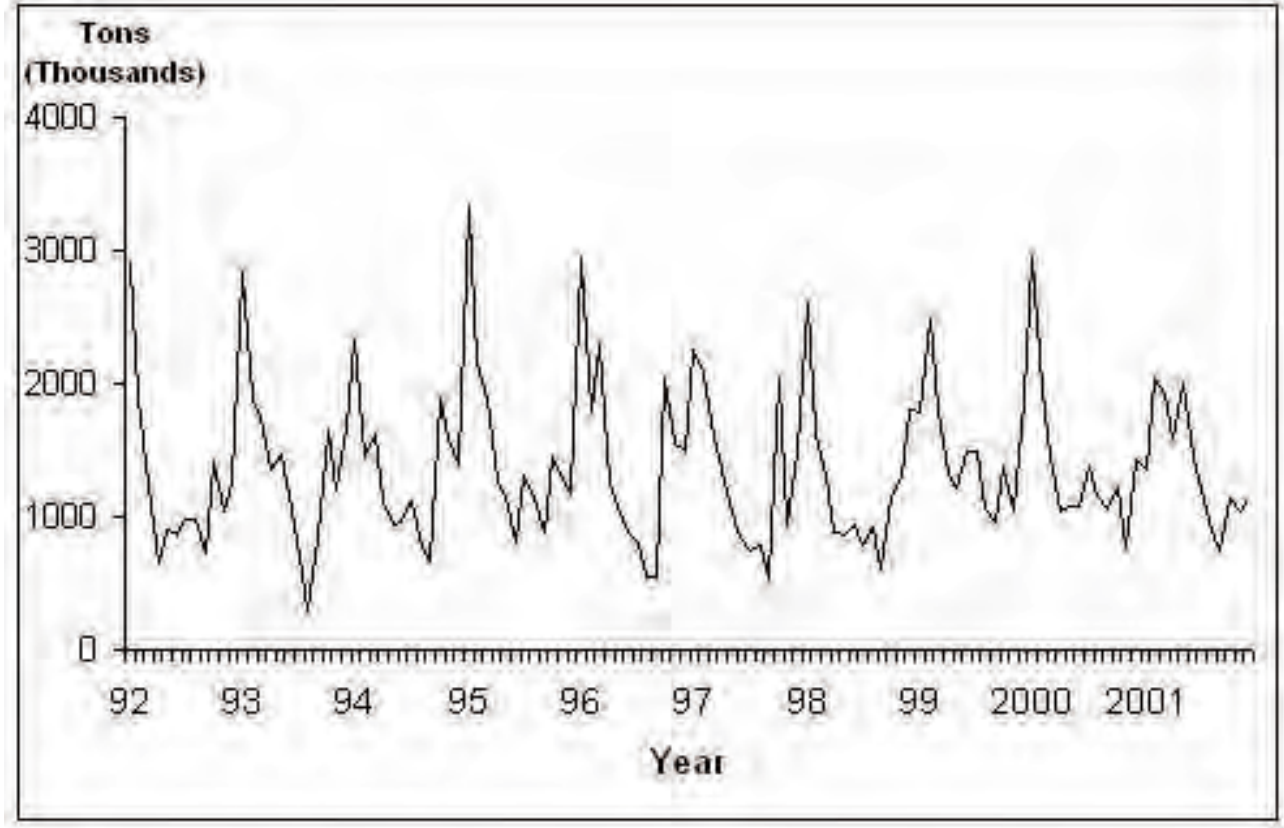


Freight Transportation Demands

Other transportation modes may influence grain barge demands on the examined waterways. A north-south railroad [Illinois Central Gulf (ICG) now operated by Canadian National (CN)] linking Illinois and the surrounding region to lower Mississippi River ports may offer competition to the grain barge industry operating on the Illinois River. Similarly, selected railroads [Burlington Northern Santa Fe (BNSF) and Union Pacific (UP)] operating in Minnesota and Iowa may compete with the upper Mississippi barge industry through their links to Pacific Northwest ports. Potentially, a reduction in rail rates to the PNW will increase rail grain shipments to the Pacific Northwest, while reducing the amount of grain shipped by barge on the inland waterways. Railroads and trucks may complement barge transportation since they are used to assemble grain to river ports. If the rate associated with a complementary mode increases, the quantity of grain shipped to the river may decrease. Accordingly, the demand for grain barge traffic would decrease or shift to the left. Conceptually, ocean freight rates may also influence grain barge demand on the upper Mississippi and Illinois Rivers. A relatively high ocean freight rate linking lower Mississippi River ports to world importing regions may adversely affect grain barge demand on the upper Mississippi and Illinois Rivers, whereas low ship rates may increase this demand.

Floods and droughts may impact the navigability of the inland waterway. When a flood or drought occurs, barge demand may be weakened because the river is not navigable or it becomes a less efficient transport artery. Similarly, grain barge demand may be influenced by seasonal factors. During the grain harvest season, the demand for grain barge service may increase because of expanded grain supply. In the winter season, the upper Mississippi River is typically frozen and not navigable over extended segments, so grain barge traffic is nearly nonexistent. In contrast, the Illinois River is generally navigable throughout the year; therefore, its grain barge traffic is expected to increase in winter to meet the year-around demand for grain at lower Mississippi River ports.

\section{VARIABLES AND DATA}

Table 1 includes the definition of variables in the estimated upper Mississippi and Illinois River grain barge demand equations, and the descriptive statistics for all continuous variables are presented in Table 2. Monthly data from January 1992 through December 2001 are used to estimate the grain barge demand equations.

\section{Upper Mississippi River}

The following variables were incorporated into the upper Mississippi River's grain barge demand equation: (1) quantity of grain shipped by barge per month $\left(\mathrm{BQUM}_{i}\right)$, the dependent variable; (2) two lagged dependent variables $\left(\mathrm{BQUM}_{t-1} \text { and } \mathrm{BQUM}_{t-12}\right)^{1} ;$ (3) grain barge rate $\left(\mathrm{BRSP}_{i}\right)$; (4) export grain demand at the lower Mississippi River ports (GEXPQ); (5) Iowa corn price $\left(\mathrm{CNIAP}_{i}\right)$, which is a measure of domestic grain demand; (6) Iowa and Minnesota grain supply $\left(\right.$ GSTOCKUM $\left._{t-1}\right)$; (7) rates of competing and complementary transportation modes (ROPNW OGULF2JP $_{i}$, RRMR ${ }_{i}$; and (8) binary variables (FROZEN, FLOOD, FEB1999 and WATERLVL). ${ }^{2}$

BQUM $_{i}$ represents the quantity of grain, primarily corn and soybeans, shipped per month from the upper Mississippi River to the lower Mississippi River port area. It is grain that originated on that segment of the Mississippi River extending from Minneapolis to Lock 24 near St. Louis. During the study period, BQUM ${ }_{i}$ averaged about 1.7 million tons per month (Table 2). As shown in Figure 2, peak flows typically occur during the spring and fall seasons. An Illinois River grain barge rate $\left(\mathrm{BRSP}_{i}\right)$, a spot barge rate, was adopted as a proxy for barge rates linking the upper Mississippi River to lower Mississippi River ports because of a data problem with upper Mississippi River rates that centered on the river closing for the winter season. Available grain barge rates on the upper Mississippi and the Illinois River rates were highly correlated (0.99) since transportation equipment moves freely between rivers and similar economic forces influence both arteries. The 
Table 1: Definition of Grain Barge Demand Variables for Upper Mississippi and Illinois Rivers

\begin{tabular}{|c|c|}
\hline Variables & Definitions \\
\hline \multicolumn{2}{|l|}{ Mississippi River } \\
\hline $\mathrm{BQUM}_{i}$ & Quantity of grain entering upper Mississippi River in month ${ }_{i}(1000$ tons) \\
\hline GSTOCKUM $_{i}$ & Quantity of grain stock in Minnesota and Iowa in month (1000 tons) \\
\hline CNIAP $_{i}$ & East Iowa corn price in month $(\$ /$ ton$)$ \\
\hline $\mathrm{ROPNW}_{i}$ & Rail rate plus ocean rate linking north central U.S. to Japan in month ${ }_{i}(\$ /$ ton$)$ \\
\hline $\mathrm{RRMR}_{i}$ & Rail rate to upper Mississippi River elevators in month $_{i}(\$ /$ ton $)$ \\
\hline FROZEN & Binary variable for frozen river: December, January, February =1; others $=0$ \\
\hline FLOOD & Binary variable for river closure caused by flood: flood $=1$; otherwise $=0$ \\
\hline FEB1999 & Binary variable for month February 1999 \\
\hline \multicolumn{2}{|l|}{ Illinois River } \\
\hline $\mathrm{BQIL}_{i}$ & Quantity of grain entering Illinois River in month ${ }_{i}$ (1000 tons) \\
\hline CNILP $_{i}$ & Central Illinois corn price in month $_{i}(\$ /$ ton $)$ \\
\hline GSTOCKIL $_{i}$ & Quantity of grain stocks in Illinois in month $_{i}(1000$ tons $)$ \\
\hline $\mathrm{RRGF}_{i}$ & Rail grain rate from Illinois to Mississippi Gulf in month $(\$ /$ ton $)$ \\
\hline WINTER & Binary variable for winter: January, February, March $=1$; otherwise $=0$ \\
\hline \multicolumn{2}{|l|}{ For Both Rivers } \\
\hline $\mathrm{BRSP}_{i}$ & Grain barge rate in month $_{i}$ \\
\hline $\mathrm{GEXPQ}_{i}$ & Quantity of grain exported at Mississippi Gulf ports in month $_{i}(1000$ tons) \\
\hline OGULF2JP & Ocean freight rate from U.S. Gulf to Japan in month $_{i}(\$ /$ ton $)$ \\
\hline WATERLVL & Binary variable for low water level: if water level is low $=1$; otherwise $=0$ \\
\hline
\end{tabular}

barge rate exhibits strong seasonality with the peak rate generally occurring between September and November: the average value of the barge rate was $\$ 8.04$ per ton over the study period.

Grain exports at lower Mississippi River ports (GEXPQ $)_{i}$ served as the proxy for foreign grain demand. The average quantity of grain exported per month at lower Mississippi River ports was 4.7 million tons (Table 2). Corn is the primary grain produced in the Corn Belt, and it is exported largely through lower Mississippi River and Pacific Northwest ports.

Grain stocks in Minnesota and Iowa $\left(\mathrm{GSTOCKUM}_{\mathrm{t}-1}\right)$ represent regional grain supply. Grain stocks are recorded quarterly, hence the need to interpolate the quarterly statistics for purposes of generating monthly values. Because stocks reflect the quantities on the first day of a quarter, these numbers may better measure stocks in the preceding quarter. For this reason, a one period lag was incorporated into the transformed data. The lagged combined mean grain stock levels in Minnesota and Iowa were 53.7 million tons per month (Table 2). Domestic demand for corn and soybeans in proximity of the river was represented in the grain barge equation by an east Iowa corn price $\left(\mathrm{CNIAP}_{i}\right)$. Higher domestic corn prices suggest increased domestic corn demand, which is expected to have a negative influence on grain barge traffic, almost all of which is exported. 
Freight Transportation Demands

Table 2: Statistical Summary of Variables Included in Demand Equations

\begin{tabular}{|c|c|c|c|c|c|}
\hline Variables & Unit & Mean & $\begin{array}{l}\text { Standard } \\
\text { Deviation }\end{array}$ & Minimum & Maximum \\
\hline \multicolumn{6}{|l|}{ Mississippi River } \\
\hline BQUM & 1,000 tons & $1,737.46$ & $1,048.73$ & 1.85 & $3,504.92$ \\
\hline GSTOCKUM & 1,000 tons & $53,774.94$ & $22,967.11$ & $6,674.90$ & $103,231.90$ \\
\hline CNIAP & $\$ /$ ton & 80.53 & 23.01 & 48.02 & 166.32 \\
\hline ROPNW & $\$ /$ ton & 38.50 & 3.68 & 31.79 & 46.52 \\
\hline RRMR & $\$ /$ ton & 8.06 & 2.38 & 4.49 & 20.42 \\
\hline \multicolumn{6}{|l|}{ Illinois River } \\
\hline BQIL & 1,000 tons & $1,367.50$ & 570.65 & 293.50 & $3,324.55$ \\
\hline CNILP & $\$ /$ ton & 86.21 & 23.01 & 52.91 & 172.83 \\
\hline GSTOCKIL & 1,000 tons & $26,252.68$ & $13,267.17$ & $2,737.90$ & $55,833.29$ \\
\hline RRGF & $\$ /$ ton & 9.48 & 1.68 & 6.32 & 17.43 \\
\hline \multicolumn{6}{|l|}{ Both Rivers } \\
\hline BRSP & $\$ /$ ton & 8.04 & 2.62 & 3.94 & 14.90 \\
\hline GEXPQ & 1,000 tons & $4,732.45$ & $1,123.48$ & $2,287.21$ & $7,310.14$ \\
\hline OGULF2JP & \$ / metric ton & 22.62 & 4.93 & 12.51 & 35.47 \\
\hline
\end{tabular}

The sum of two transportation rates, the rail rate for corn from locations in western Minnesota and Iowa to Pacific Northwest ports and the ocean grain rate from Pacific Northwest ports to Japan $\left(\mathrm{ROPNW}_{i}\right.$ ) is included to represent a competing export route to the Mississippi River waterway. The ocean grain rate linking the U.S. Gulf to Japan (OGULF2JP $)$ is included to capture the impact of this rate on upper Mississippi and Illinois River grain barge demands. ${ }^{3}$ In addition, the railroad rate from central Minnesota origins to upper Mississippi River elevators (RRMR) is included to represent a complementary mode to barge transportation on the upper Mississippi. Surveys of grain handlers in Iowa (Baumel, Hommes, Gervais and McVey 2001) and Minnesota (Fruin and Tiffany 2002) indicated from half to nearly $70 \%$ of corn assembled to Mississippi River elevators in these states was transported by rail, hence railroad's selection as the complementary mode. Railroad rates for grain shipments from Minnesota and Iowa to the U.S. Gulf are not included in the analysis because of the inability to obtain a continuous monthly railroad rate data series linking Iowa and Minnesota to lower Mississippi River ports over the study period. This was the result of railroad waybill data showing limited movement from this region to lower Mississippi River ports.

Floods and freezing during the winter may have an important influence on upper Mississippi River transport demand and are represented by binary variables FLOOD and FROZEN, respectively. In general, the entire river will not close if floods occur in a particular region, however, a regional flood may cause some locks to become inaccessible, which may divert demand to other modes. During the winter, the upper Mississippi is generally frozen from mid-December to early March. Finally, a water level binary variable, WATERLVL, is included to reflect low water levels below the system of dams (south of St. Louis) on the Mississippi River system. Low water precludes efficient barge transportation and may reduce the quantity of grain transported by barge. ${ }^{4}$ 


\section{Illinois River}

Variables included in the Illinois River grain barge demand equation include (1) the dependent variable, quantity of grain shipped by barge per month (BQIL $)_{i}$; (2) a lagged dependent variable $\left(\mathrm{BQIL}_{t-12}\right) ;(3)$ grain barge rate $\left(\mathrm{BRSP}_{i}\right)$; (4) export grain demands at lower Mississippi ports (GEXPQ); (5) Illinois grain supply (GSTOCKIL ${ }_{t-1}$ ); (6) Illinois corn processor price (CNILP), which is a measure of domestic grain demand; (7) rates of complementary and competing transportation modes (RRGF ${ }_{i}$, OGULF2JP $)$; and (8) binary variables for winter (WINTER) and river water level (WATERLVL).

The variables, BRSP ${ }_{i}$, GEXPQ ${ }_{i}$, OGULF2JP ${ }_{i}$ and WATERLVL are defined above. The dependent variable in the Illinois River demand equation (BQIL ( $_{i}$ is the monthly quantity of grain shipped by barge on the Illinois River; during the study period it averaged 1.4 million tons (Table 2). As evidenced by Figure 3, seasonality in shipments peaks during the fall and winter seasons.

Grain stocks in Illinois $\left(\right.$ GSTOCKIL $_{t-1}$ ) represent the regional supply of grain. Similar to GSTOCKUM $_{\mathrm{t}-1}$, it has been converted from a quarterly to a monthly series and lagged one time period. The average stock of grain in Illinois during the study period was about 26 million tons (Table 2). A processor corn price in central Illinois (CNILP) serves as a proxy for domestic grain demand.

As in the upper Mississippi demand equation, the ocean grain rate from U.S. Gulf ports to Japan (OGULF2JP) is included. Rail rates linking east central Illinois to the lower Mississippi River ports $\left(\mathrm{RRGF}_{i}\right)$ are included and are assumed to represent competition for the barge mode.

When the upper Mississippi River closes in December, many of the towboats and barges migrate to the Illinois River. Repositioning and loading this equipment on the Illinois River requires two to four weeks. Therefore, the winter binary variable included in the Illinois River equation is for January, February, and March; this involves a month lag in the FROZEN binary variable included in the upper Mississippi equation.

The quantity of grain transported on each river, BQUM $\mathrm{B}_{i}$ and BQIL $\mathrm{B}_{i}$, is collected by the U.S. Army Corps of Engineers and archived by the Tennessee Valley Authority in Knoxville, Tennessee. These data were released for research purposes by a request from the Agricultural Marketing Service (AMS) of the U.S. Department of Agriculture (USDA). The Agricultural Marketing Service surveys, on a weekly basis, barge companies to collect grain barge rates (BRSP ${ }_{\mathrm{i}}$ ); accordingly, these data were the source of this information (USDA 2005a). The Agricultural Marketing Service also provided monthly grain exports at lower Mississippi River ports $\left(\mathrm{GEXPQ}_{i}\right)$ and ocean grain rates linking U.S. Gulf ports to Japan (OGULF2JP ${ }_{i}$ ) and Pacific Northwest ports to Japan (USDA 2002). The ROPNW ${ }_{i}$ variable was constructed by aggregating ocean grain rates that link the Pacific Northwest ports to Japan and the rail rates linking western Minnesota to the Pacific Northwest ports. Rail rate data linking western Minnesota to Pacific Northwest ports and $\mathrm{RRMR}_{i}$ and $\mathrm{RRGF}_{i}$ were taken from the Carload Waybill Sample that can be obtained from the Surface Transportation Board of the U.S. Department of Transportation (USDOT 2005). Grain stocks (GSTOCKUM, GSTOCKIL $_{i}$ ) and Illinois corn price (CNILP $)$ were obtained from the Economic Research Service of the U.S. Department of Agriculture (2003). Iowa corn price data (CNIAP $i$ ) was provided by the Iowa Department of Agriculture and Land Stewardship (2005). Flood data (FLOOD) were collected by the U.S. Army Corps of Engineers, Rock Island District, and was obtained through the Navigation Information Connection of the U.S. Army Corps of Engineers (USACE 2003a). The Mississippi River water level data (WATERLVL) were obtained from the water level archives maintained by the U.S. Army Corps of Engineers, St. Louis District (USACE 2005). 
Freight Transportation Demands

\section{MODEL ESTIMATION}

Initially, freight demands were estimated by ordinary least squares (OLS) to examine the endogeneity issue, then Seemingly Unrelated Regression (SUR) was employed. The discussion of empirical results centers on the SUR estimates because of the superiority of these estimates.

\section{OLS estimates}

Several econometrics tests (residual tests) were conducted to examine the quality of the OLS results. Residual tests, including correlograms of squared residuals, normality test, serial correlation Lagrange Multiplier (LM) test, autoregressive conditional heteroskedasticity (ARCH) LM test, and White's heteroskedasticity test were carried out for both grain barge demand models. The estimated grain barge demand equations generally performed well in the residual tests.

Conceptually, the quantity and price for barge service are jointly determined. Therefore, a simultaneous bias may occur with the OLS estimates since barge rates may be correlated with the residuals, yielding biased and inconsistent estimates. The concerns regarding endogeneity center on the explanatory variables for barge rates and rates of other transportation modes.

For the upper Mississippi River, BRSP, ROPNW, OGULF2JP, and RRMR are four potential endogenous variables. Identification requires at least four instrument variables (Baltagi 2002). The instruments must be exogenous variables that are uncorrelated with the residual term in the demand equation. The instrument variables selected for barge rate (BRSP) include a lagged term of barge rate, diesel price, and the wage index for transportation and warehouse industries. The lagged barge rate was selected as an instrument as it would not be affected by current barge demand. Diesel price (DIESEL) and wage index (WAGE) were selected as they are shifters of the supply curve for transportation services, thus fitting the exogeneity and relevance condition necessary for instruments. In a similar fashion, for the rates of other transportation modes (ROPNW, OGULF2JP, RRMR), the lagged term of each variable, diesel price, and the wage index for transportation and warehouse industries are selected as instruments. Diesel price was available at the website of the U.S. Department of Energy (USDOE 2003), while the wage index was collected from the Bureau of Labor Statistics at the U.S. Department of Labor (USDOL 2003).

If instruments explain very little of the variation in endogenous variables, the so-called weak instruments can make the 2SLS estimator biased (Stock and Watson 2003). Stock and Watson (2003) offer a Rule of Thumb (p. 350) for identifying weak instruments: "when there is a single endogenous regressor, a first-stage F-statistic less than 10 indicates that the instruments are weak." Four potential endogenous variables are in this equation; hence, the situation is somewhat complicated. However, the Rule of Thumb was applied to offer insight on the instruments validity. For the BRSP equation, three instruments, lagged BRSP $\left(\mathrm{BRSP}_{\mathrm{t}-1}\right)$, diesel price, and wage index, were statistically significant and the $F$-statistic was 16.16 , which indicates the instruments are not weak. The $F$-statistics associated with the three other equations (ROPNW, OGULF2JP, RRMR) were 16.52, 106.40, and 3.19, respectively. The weak instruments for RRMR may influence the performance of 2SLS estimators, which were further evaluated with the Hausman test.

The Hausman specification test (Hausman 1978) was used to test for bias or inconsistency of an estimator. The null hypothesis associated with this test is $H_{0:} E(u / X)=0$ versus $H_{1:} E(u / X)$ $\neq 0$, where the $u$ is the residual term and $X$ represents the regressors. Two ordered estimators are necessary to conduct this test. In this study, the Hausman test is based on the difference between the OLS and 2SLS estimators. Failing to reject the null hypothesis implies that the OLS estimators are consistent. The Hausman test statistic for this model was 4.67 and was asymptotically distributed as $\chi_{14}^{2}$. This outcome was not significant, which indicates the 2SLS and OLS estimates are not statistically different given the choice of instruments and the model specification. Therefore, the 2SLS method is not preferred over OLS. 
Following a similar procedure, OLS and 2SLS methods were used to estimate the Illinois River demand equation. The evaluated endogenous variables included barge rates (BRSP), rail rates linking Illinois with lower Mississippi River ports (RRGF), and ocean grain rates connecting U.S. Gulf ports to Japan (OGULF2JP). The Hausman test showed the 2SLS method was not preferred over OLS. The details of all tests and OLS estimates are available upon request.

\section{System Estimation by SUR}

Conceptually, grain barge demands on the two rivers are related. That is, the residuals associated with one estimated barge demand equation may be correlated with residuals from the other estimated equation because there are omitted variables that influence grain movement on both rivers. If the covariance of the residuals generated from the two estimated demand equations is statistically different from zero, Seemingly Unrelated Regression should be employed since the OLS estimates are inefficient. Zellner's SUR model was adopted, and the covariance matrix of the residuals generated from the two barge demand equations was as follows (elements are presented in the order listed across the top of Cov the matrix):

(2) $\operatorname{Cov}=\begin{array}{rc}\text { BQUM } & \text { BQIL } \\ 0.1453 & \\ 0.0207 & 0.0521\end{array}$

The covariance of residuals from the two demand equations is about 0.0229. A likelihood ratio test was carried out where the null hypothesis was $\sigma_{i j}=0$. The asymptotically distributed statistic for this test was 6.12, thus rejecting the null hypothesis. Therefore, OLS estimates are not efficient and the SUR estimates are superior.

\section{RESULTS}

The estimated coefficient for each continuous variable in the Mississippi River and Illinois River equations is an elasticity, since the data are converted to natural logarithms. The elasticity measures the percent change in the dependent variable (quantity of grain transported by barge on the river) associated with a $1 \%$ change in an explanatory variable. The estimated coefficients and associated significance for the Upper Mississippi and Illinois River grain barge demands are presented in Table 3.

\section{Upper Mississippi}

For BQUM $t-1$ and BQUM $t-12$, expected signs are obtained—and both are highly significant (1\% level). For barge rate, an expected negative relationship between barge rate (BRSP) and grain barge demand is observed. The grain barge rate elasticity is -0.427 , indicating grain barge demand is inelastic, and the t-statistic associated with the BRSP variable indicates it is statistically significant at the $1 \%$ level. The quantity of grain exported via lower Mississippi River ports (GEXPQ) (foreign grain demand) influences grain barge demand in a positive manner and is significant at the $1 \%$ level. The estimated elasticity of 0.926 implies a $1 \%$ increase in export grain demand will generate almost a $1 \%$ increase in grain transported on the river. As expected, there is a positive relationship between lagged grain stocks in Minnesota and Iowa $\left(\right.$ GSTOCKUM $\left._{t-1}\right)$ and grain barge demand on the upper Mississippi River. However, the GSTOCKUM variable is not statistically significant. The east Iowa corn price (CNIAP) — a proxy for domestic grain demand — has the expected negative sign, but it is not statistically significant.

Unexpectedly, the variable representing the combined rail rate from the north central U.S. to the Pacific Northwest and the linking ocean rate to Asia (ROPNW) have a negative coefficient, and 


\begin{tabular}{|c|c|c|}
\hline & Coefficient & t-statistics \\
\hline \multicolumn{3}{|c|}{ Mississippi River } \\
\hline $\mathrm{BQUM}_{t-1}$ & 0.168 & $4.89 * * *$ \\
\hline $\mathrm{BQUM}_{t-12}$ & 0.300 & $5.94 * * *$ \\
\hline $\mathrm{BRSP}_{i}$ & -0.427 & $-2.66 * * *$ \\
\hline $\mathrm{GEXPQ}_{i}$ & 0.926 & $4.68 * * *$ \\
\hline GSTOCKUM $_{t-1}$ & 0.077 & 0.81 \\
\hline $\mathrm{CNIAP}_{i}$ & -0.219 & 1.24 \\
\hline $\mathrm{ROPNW}_{i}$ & -0.108 & -0.19 \\
\hline OGULF2JP $_{i}$ & 0.266 & 1.09 \\
\hline $\mathrm{RRMR}_{i}$ & -0.226 & -1.43 \\
\hline FROZEN $_{i}$ & -1.600 & $-9.40 * * *$ \\
\hline FLOOD & -0.592 & $-3.21 * * *$ \\
\hline FEB1999 & -4.371 & $-11.16 * * *$ \\
\hline WATERLVL & -0.256 & -1.54 \\
\hline Constant & -2.552 & -1.10 \\
\hline \multicolumn{3}{|l|}{ Illinois River } \\
\hline $\mathrm{BQIL}_{t-12}$ & 0.317 & $4.29 * * *$ \\
\hline $\mathrm{BRSP}_{i}$ & -0.213 & $-2.13 * *$ \\
\hline $\mathrm{GEXPQ}_{i}$ & 0.676 & $6.08 * * *$ \\
\hline CNILP $_{i}$ & -0.375 & $-3.09 * * *$ \\
\hline GSTOCKIL $_{t-1}$ & 0.013 & 0.26 \\
\hline $\mathrm{RRGF}_{i}$ & -0.096 & -0.62 \\
\hline OGULF2JP $_{i}$ & 0.293 & $2.69 * * *$ \\
\hline WINTER & 0.278 & $3.71 * * *$ \\
\hline WATERLVLD & -0.290 & $-2.96 * * *$ \\
\hline Constant & 0.417 & 0.40 \\
\hline
\end{tabular}

*** Significant at $1 \%$ level, ** Significant at $5 \%$ level 
the ocean freight rate from the U.S. Gulf to Asia (OGULF2JP) have a positive coefficient; however, neither is significant. ${ }^{5}$ The lack of statistical significance may suggest the influence of the ocean freight rate is modest, or it is not measured effectively with the model. The RRMR variable has the expected negative sign but is not significant at usual levels.

Most portions of the upper Mississippi River are not navigable in December, January, and February because the river is frozen. Since barges cannot service this demand, there is an expected decline in the quantity of grain transported by barges during this period, and results confirm this expectation. The FROZEN and FLOOD binary variables are highly significant (1\% level) and with a negative sign. The water level dummy (WATERLVL) is also a measure of navigability: it has the expected negative sign but is not significant.

\section{Illinois River}

The $\mathrm{BQIL}_{\mathrm{t}-12}$ variable is highly significant (1\% level), suggesting the importance of seasonality to Illinois River grain barge demand. As expected, a negative sign is associated with the barge rate (BRSP) and the associated own-price elasticity is estimated to be -0.213 ( $5 \%$ level). Thus, a $1 \%$ increase in the grain barge rate will diminish quantity of barge transportation service purchased by $0.213 \%$, hence an inelastic relationship. Grain export level (foreign demand) at lower Mississippi River ports (GEXPQ) is found to have an important influence on grain barge demand with an elasticity of 0.676 (1\% level). An increase in the Illinois corn processor price (CNILP) is expected to attract grain to the domestic market and away from the export market, therefore reducing grain barge demand on the Illinois River. The estimated negative sign and coefficient suggest a $1 \%$ increase in domestic processor price (CNILP) will lower the quantity of grain shipped on the Illinois River by $0.375 \%$ ( $1 \%$ level). The lagged grain stock variable (GSTOCKIL $\left.{ }_{t-1}\right)$, a proxy for hinterland grain supply, has the anticipated positive sign; however, it is not significant. A positive relationship was expected between railroad rates that link Illinois origins to lower Mississippi River ports (RRGF) and grain barge demands on the Illinois River. The RRGF variable, however, is not found to be statistically significant, and the associated coefficient does not have the expected sign.

The influence of the ocean grain rate on Illinois River grain transport demand was to be captured with the OGULF2JP variable. Unexpectedly, the sign on this variable's estimated coefficient is positive and statistically significant, suggesting high ocean rates are associated with large demands for grain barge transportation. It is hypothesized that the positive sign is related to the positive correlation found between foreign grain demand, and barge and ocean ship rates. The positive sign may occur because an increase in foreign grain demand increases the demand for both modes, and this tends to increase barge and ocean rates.

The winter variable (WINTER), a binary variable, is found to be positive and significant at the $1 \%$ level. Thus, statistical results confirm that Illinois River grain barge demand shifts to the right during the winter when the upper Mississippi is largely frozen. Water level (WATERLVL), a binary variable, is also significant at the $1 \%$ level and, as expected, with a negative sign. This suggests grain traffic on the Illinois River is reduced during periods of low water in the segment of the Mississippi River south of St. Louis. This occurs because grain export traffic from the Illinois River traverses this section of the Mississippi River on its journey to lower Mississippi River ports.

The estimated structural demands for the upper Mississippi and the Illinois River are similar. First, grain barge rate is a statistically important factor influencing grain barge demands, and these demands are inelastic. This was revealed by an estimated short-run elasticity of -0.427 for the upper Mississippi River and -0.213 for the Illinois River. Second, grain exports (foreign demand) as reflected at lower Mississippi River ports have an important impact on grain barge demands. This influence is greatest on the upper Mississippi River, with an estimated elasticity of 0.926 . Local/regional grain supply, as represented by grain stocks, does not have an important influence on river transport demand, even though theory suggests its possible role as a demand shifter. The analysis suggests domestic grain demands as measured by a nearby domestic grain price have a 


\section{Freight Transportation Demands}

strong statistical influence on Illinois River barge transport demand but little influence on the upper Mississippi barge demands. The Illinois grain price was a processor price, whereas the Iowa price (upper Mississippi River analyses) was a farm price because of the unavailability of a processor price for Iowa. Researchers speculate that a processor price may be a better proxy of domestic demand and had an Iowa processor price been available, it may have revealed domestic grain demands in Iowa to be statistically important. Third, navigability conditions as influenced by winter, flood and water level have an influence on river grain transportation demand. And, the Illinois River's increased grain barge demand during the winter confirms its expected relationship with the upper Mississippi, whose grain traffic subsides in the winter. Finally, the influence of other transportation modes on river grain transportation demands is modest and, in some cases, has an unexpected relationship to demand. The expected influence of ocean grain rate on grain barge demand is not confirmed by the analyses.

The estimated grain transport demand elasticities are representative of the short-run. However, by manipulating coefficients associated with the lagged dependent variables, it is possible to calculate a long-run demand elasticity following the procedure of Davidson and MacKinnon (1993). ${ }^{6}$ For the upper Mississippi River, the short-run own price elasticity is estimated to be -0.427 while the calculated long-run elasticity is $-0.803=[-0.427 /(1-0.168-0.300)]$, implying that a $1 \%$ increase in the grain barge rate will reduce the quantity demanded by about $0.8 \%$ in the long run. The Illinois River's short-run own price elasticity is estimated to be -0.213 , while the calculated longrun elasticity is $-0.312=[-0.213 /(1-0.317)]$.

\section{IMPLICATIONS OF FINDINGS}

Results in Table 3 show low water levels (WATERLVL) in the mid-section of the Mississippi River (south of St. Louis to Cairo) unfavorably influence grain traffic on the Illinois River. This finding suggests that federal water release policy as implemented by dams on the Missouri River (Montana, and North and South Dakota) has an influence on the examined grain barge demands. Low water levels on the Mississippi River typically occur south of St. Louis where there are no dams to assure 9 feet of water necessary for efficient navigation. The Missouri River empties into the Mississippi River just north of St. Louis and is the source for up to $60 \%$ of the water flowing on the middle Mississippi (St. Louis, Missouri to Cairo, Illinois) (USDA 2005b). Water release policy and the outcome of debate over this policy (recreation versus Missouri River navigation) influence Missouri River water flow and subsequently middle Mississippi water flow and, as indicated by this study, the demand for grain transportation on the Illinois River.

The measurement of benefits from river infrastructure improvements is based conceptually upon transportation demands that relate barge companies willingness-to-pay for different quantities of project output. These analyses show grain barge demands to be inelastic in the short run but, more importantly, in the long-run to approach unitary elasticity on the upper Mississippi (-0.803), while being comparatively inelastic on the Illinois River (-0.312). This finding implies marginal benefits from incremental infrastructure additions may decline at a less rapid rate on the upper Mississippi than the Illinois River; therefore, similar improvements on each waterway may not be warranted.

\section{CONCLUSION}

The upper Mississippi and Illinois Rivers are important freight transport arteries in the U.S. inland waterway system. Grain is the focus of this study because it is the predominant commodity transported on these rivers. Using monthly data from 1992 to 2001, the structural demands for grain barge transportation on each waterway is estimated. There are several notable findings. First, statistical tests show SUR methods yield superior estimates of demand because omitted common forces appear to influence grain barge demands on both rivers. Second, on both rivers, the estimated 
short- and long-run grain transport demands are price inelastic. The estimated short-run own price demand elasticities for the upper Mississippi and Illinois Rivers are -0.427 and -0.213 , respectively, while the calculated long-run elasticities were -0.803 and -0.312 respectively. Grain exports (foreign demand) are also an important force influencing grain barge demand. The estimated elasticity for the upper Mississippi River is 0.926, while an elasticity of 0.676 is estimated for the Illinois Riverand both are highly significant. In addition, domestic grain demand as measured by Illinois grain processor price has an important influence on Illinois River grain barge demand with an estimated elasticity of -0.375 . Researchers speculate that a similar finding may have been found for the upper Mississippi had a processor grain price series been available. The winter season, because of navigability concerns on the upper Mississippi, reduce quantity transported on this waterway but increase demand on the Illinois River, which is navigable year-round. Also notable are floods and droughts that unfavorably influence barge transport demand. The influence of other transportation modes on grain barge demand is unclear since some results did not concur with expectations, and often they were not statistically significant. Additional research into these forces and their influence on upper Mississippi and Illinois River grain barge demands may be warranted.

Study results offer some guidance to researchers examining the economic feasibility of improving navigation infrastructure on the upper Mississippi and Illinois Rivers-a debated issue among government agencies and interest groups. First, the analyses suggests that a comprehensive study into future foreign grain demand is critical since it is an important force influencing river grain traffic. And, of equal importance is the need to consider complementary/competitive transportation links (e.g. Panama Canal) to the international grain market and their likely impact on competitiveness of U.S. Gulf ports. Further, because domestic grain demands also influence river traffic, it is important to carry out a comprehensive analysis of these future demands with consideration given to federal policies and their effect on domestic grain demand. Finally, the analysis shows that demand for river grain transportation is influenced by water release policies of dams on rivers (e.g., Missouri River) that flow into the Mississippi River system and whose volume is important in maintaining adequate water depth for efficient navigation on the examined rivers. A clarification of the water release policies is important to understanding future transportation demands for these rivers. Freight demand analysis is a precursor of any defendable study into the economic feasibility of improving navigation infrastructure on the upper Mississippi and Illinois Rivers.

\section{Endnotes}

1. The length of lag was determined by the Schwartz criterion (Schwartz 1978). Multiple lag structures were tested and based on the Schwartz test statistic; one- and twelve-month lags of the dependent variables were selected. The lagged dependent variable, BQUM $\mathrm{t}_{\mathrm{t}-1}$, is used to measure the influence of barge movement in the previous month, while the lagged dependent variable, $\mathrm{BQUM}_{\mathrm{t}_{12}}$, is included to evaluate the seasonality pattern that evolved every 12 months (Figure 2).

2. FEB1999 is a binary variable introduced for estimation purposes. Initial estimation showed the value of the BQUM variable in February 1999 to have an important impact on the estimated demand due to its abnormal value. A review of happenings during February 1999 did not suggest a responsible force, accordingly it was assumed to be a data-entry error.

3. Gulf of Mexico grain exports represent grain exports to all destinations, whereas the ocean rate to Japan is associated with only a portion of total Gulf grain exports. The correlation coefficient between these two variables is only 0.217 .

4. A barge company official in St. Louis informed that when the water level at a selected water gauge in the St. Louis area is 5 feet or less, navigation problems often develop for barge traffic south of St. Louis. Daily water stage levels were averaged to yield a monthly average from 
Freight Transportation Demands

which a binary variable was constructed that included a 1 when water depths were 5 feet or less.

5. The correlation between OGULF2JP and ROPNW was high (0.814); therefore, an additional model was estimated that included ocean rate spreads (Gulf rates versus Pacific Northwest rates to Asia) rather than Gulf rates (OGULF2JP). The new SUR results are very similar to those presented in the paper (with inclusion of the OGULF2JP variable). In particular, the same variables are significant in both models and the significant variables have identical signs in each model. Further, the magnitude of the estimated coefficients in the two models was similar.

6. In equation (1), barge traffic $\left(q_{b, t}\right)$ is a function of the lagged barge movement $\left(q_{b, t-i}\right)$, barge rate $\left(p_{b, t}\right)$ and other variables $\left(x_{b, t}\right)$. A simple model can be written as $q_{b, t}=\alpha+\beta^{*} q_{b, t-i}+\gamma^{*} p_{b, t}+\delta^{*} x_{t}$

$+\mu_{t .}$ In the long run, $q_{b, t}, p_{b, t}$, and $x_{t}$ would converge to steady-state long-run equilibrium values $q_{b}{ }^{*}, p_{b}{ }^{*}$, and $x^{*}$ and the equation becomes $q_{b}{ }^{*}=\alpha+\beta^{*} q_{b}{ }^{*}+\gamma^{*} p_{b}{ }^{*}+\delta^{*} x^{*}$. Thus, the long-run derivative of $q_{b}{ }^{*}$ with respect to $p_{b}{ }^{*}$ is $[\gamma /(1-\beta)]$, which is the long-run elasticity formulation used in this study.

\section{References}

Babcock, M. W. and H. W. German. "Forecast of Water Carrier Demand to 1985.” Proceedings of the Transportation Research Forum 24(1),(1983):249-257.

Baltagi, B. H. Econometrics. 3rd ed. Springer, Berlin, 2002.

Baumel, C. P., H. Hommes, J. Gervais and M. McVey. The Iowa Grain Flow Survey: Where and How Iowa Grain Producers and Country Elevators Shipped Corn and Soybeans During September 1, 1999 - August 31, 2000. Iowa State University Extension, October 2001.

Boyer, K. D. Principles of Transportation Economics. Addison-Wesley, Reading, MA, 1997.

Boyer, K. D. and W. Wilson. Estimation of Demands at the Pool Level. U.S. Army Corps of Engineers, Institute of Water Resources, 2005. http://www.corpsnets.us/inlandnav.cfm.

Dager, C., L. Bray, C. Murphree and C. Leibrock. Elasticity of Demand for Barged Grain Shipments on the Upper Mississippi and Illinois Waterway. U.S. Army Corps of Engineers, Huntington, West Virginia, 2004.

Davidson, R. and J. G. MacKinnon. Estimation and Inference in Econometrics. Oxford University Press, New York, 1993.

Fruin, J. and D. Tiffany. Where Does Minnesota's Grain Crop Go? An Analysis of Minnesota Elevator Grain Shipments for the Period 7/99 - 6/00. Staff Paper P02-9, Department of Applied Economics, College of Agricultural, Food, and Environmental Sciences, University of Minnesota, September 2002.

Harnish, G. and J. Dunn. "A Short-Run Analysis of Grain Barge Rates on the Mississippi River System.” Proceedings of the Transportation Research Forum 40, (1998):557-572.

Hausman, J. A. “Specification Tests in Econometrics.” Econometrica 4, (1978):1251-1272.

Hendrickson, K. and W. Wilson. A Model of Spatial Market Areas and Transportation Demand. U.S. Army Corps of Engineers, Institute of Water Resources, 2005. http://www.corpsne ts.us/inlandnav.cfm.

Iowa Department of Agriculture and Land Stewardship. Agricultural Marketing Bureau, 2005. http://www.agriculture.state.ia.us/historic.html

Miljkovic, D., G. K. Price, R. J. Hauser and K. A. Algozin. "The Barge and Rail Freight Market for Export-Bound Grain Movement from Midwest to Mexican Gulf: An Econometric Analysis.” Transportation Research Part E 36, (2000):127-137. 
National Research Council. Review of the U.S. Army Corps of Engineers Restructured Upper Mississippi River-Illinois Waterway Feasibility Study. Transportation Research Board, National Academies Press, Washington, D.C., 2004.

Regan, A., J. Holguin-Vergas, G. Chow and M. Sonstegaard. "Freight Transportation Planning and Logistics" in Transportation in the New Millennium: State of the Art and Future Directions. Transportation Research Board, National Research Council, 2000.

Schwartz, G. "Estimating the Dimension of a Model.” Annals of Statistics 6, (1978):461-464.

Stock, J. J. and M. W. Watson. Introduction to Econometrics. Addison-Wesley, New York, 2003.

U.S. Army Corps of Engineers (USACE). Navigation Information Connection, 2003a. http://www. mvr.usace.army.mil/navdata/flood.htm

U. S. Army Corps of Engineers (USACE). Waterborne Commerce of the United States, Part 2Waterways and Harbors Gulf Coast, Mississippi River and Antilles, 2003b.

http://www.iwr.usace.army.mil/ndc/wcsc/pdf/wcusmvgc03.pdf

U. S. Army Corps of Engineers (USACE). Final Integrated Feasibility Report and Programmatic Environmental Impact Statement for the UMR-IWW System Navigation Feasibility Study, EIS No. 04221, 2004. http://www2.mvr.usace.army.mil/umr-iwwsns/

U.S. Army Corps of Engineers (USACE). Water Level Archives. St. Louis District, 2005. http://mvswc.mvs.usace.army.mil/archive/Mississippi.html/

U.S. Department of Agriculture (USDA). Grain Transportation Report. Agricultural Marketing Service, 2002. http://www.ams.usda.gov/tmdtsb/grain/

U.S. Department of Agriculture (USDA). Feed Grain Data Delivery System. Economic Research Service, 2003. www.ers.usda.gov/db/feedgrains/

U.S. Department of Agriculture (USDA). Transportation Modes-Barge. Agricultural Marketing Service, 2005a. http://www.ams.usda.gov/tmd/TSB/barge.htm/

U. S. Department of Agriculture (USDA). Grain Transportation Report. Agricultural

Marketing Service, July 21, 2005b. http://www.ams.usda.gov/tmdtsb/grain/

U. S. Department of Agriculture (USDA). Grain Transportation Report. Agricultural Marketing Service, November 10, 2005c. http://www.ams.usda.gov/tmdtsb/grain/

U. S. Department of Agriculture (USDA). Production, Supply \& Distribution. Foreign Agricultural Service, 2005d. http://www.fas.usda.gov/psd/intro.asp?circ_id=2

U.S. Department of Energy (USDOE). Monthly Energy Review: Energy Prices. Energy Information Administration, 2003. www.eia.doe.gov/emeu/mer/prices.html.

U.S. Department of Labor (USDOL). Consumer Price Index-Urban Wage Earners and Critical Workers: U.S. Transportation. Bureau of Labor Statistics, 2003.

http://data.bls.gov/cgi-bin/surveymost?cw.

U.S. Department of Transportation (USDOT). Industry Data: Waybill, 2005. http://www.stb.dot. gov/stb/industry/econ_waybill.html/

Yu, T.H. and S. Fuller. "The Measurement of Grain Barge Demand on Inland Waterways: A Study of the Mississippi River.” Journal of the Transportation Research Forum 44(1), (2005):27-39. 
Freight Transportation Demands

Tun-Hsiang (Edward) Yu is an associate scientist in the Center for Agricultural and Rural Development (CARD) at Iowa State University. His current research primarily focuses on international trade, price analysis and agricultural transportation. Yu earned a Ph.D. in agricultural economics at Texas A\&M University, a M.S. in economics at Iowa State University and a B.A. in transportation management in Taiwan.

Jin Zhang received B.S. and M.S. degrees from Beijing University of Aeronautics and Astronautics, Beijing, China in 1994 and 1997, respectively. Since 2000, Zhang has been studying as a Ph.D. student in the Department of Agricultural Economics, Texas A\&M University, and is currently working on a dissertation dealing with business failure prediction. Zhang has papers published or forthcoming in journals including Annals of Economics and Finance and Applied Economics Letters.

Stephen Fuller is a Regents professor in the Department of Agricultural Economics at Texas A\&M University. Fuller's research focuses on agricultural marketing and transportation issues. 